\title{
PENGEMBANGAN PERANGKAT PEMBELAJARAN BERBASIS \\ MASALAH UNTUK KEMAMPUAN VISUAL THINKING \\ MATEMATIS DAN SELF EFFICACY SISWA KELAS \\ VII SMP SWASTA RAJA GARUDA MAS BESITANG
}

\author{
Meli Rama Yunita ${ }^{1}$, Edy Surya $^{2}$, Edi Syahputra ${ }^{2}$
}

\begin{abstract}
ABSTRAK
Penelitian ini bertujuan untuk mendeskripsikan bagaimana: 1) validitas, kepraktisan dan keefektifan perangkat pembelajaran berbasis yang dikembangkan dan 2) peningkatan kemampuan visual thinking matematis dan self efficacy siswa terhadap matematika dengan menggunakan perangkat pembelajaran yang dikembangkan. Jenis penelitian ini adalah penelitian pengembangan. Model pengembangan yang digunakan adalah model Thiagarajan yang terdiri atas 4 tahapan. Penelitian ini menghasilkan produk yaitu Rencana Pelaksanaan Pembelajarn (RPP), Buku Guru (BG), Buku Siswa (BS), Lembar Aktivitas Siswa (LAS), Tes Kemampuan Visual Thinking Matematis dan angket self efficacy siswa terhadap matematika. Uji coba 1 dilakukan di kelas VII-1 dan uji coba 2 dilakukan di kelas VII-2 SMP Swasta RGM Besitang. Hasil penelitian ini menunjukkan bahwa: 1) perangkat pembelajaran valid, baik dari validitas isi maupun validtas konstruk, 2) perangkat pembelajaran praktis digunakan, dilihat dari penilaian validator dan respon positif siswa terhadap perangkat pembelajaran yang dikembangkan, 3) perangkat pembelajaran efektif, dilihat dari ketuntasan belajar dan aktivitas siswa, 4) peningkatan kemampuan visual thinking siswa berada pada kategori sedang dan 5) adanya peningkatan kemampuan self efficacy siswa terhadap matematika dari uji coba 1 ke uji coba 2.
\end{abstract}

Kata Kunci: Pengembangan Perangkat Pembelajaran, Pembelajaran Berbasis Masalah, Visual Thinking dan Self Efficacy.

\section{PENDAHULUAN}

Matematika sebagai salah satu mata pelajaran yang merupakan ilmu dasar (basic science) mempunyai peran yang penting dan bermanfaat bagi perkembangan ilmu pengetahuan dan teknologi. Materi pelajaran matematika yang diajarkan di sekolah berperan dalam melatih siswa berpikir logis, kritis dan praktis, serta bersikap positif dan berjiwa kreatif karena pentingnya peranan matematika dalam kehidupan, maka dalam kurikulum pendidikan di Indonesia, matematika diajarkan disetiap jenjang pendidikan dari Sekolah Dasar hingga Sekolah Menengah Atas.

Berdasarkan Permendiknas RI Nomor 22 Tahun 2006, dijelaskan bahwa tujuan pembelajaran matematika di sekolah adalah agar peserta didik memiliki kemampuan sebagai berikut:

1. Memahami konsep matematika, menjelaskan keterkaitan antar konsep dan mengaplikasikan konsep atau algoritma, secara luwes, akurat, efisien, dan tepat, dalam pemecahan masalah.

2. Menggunakan penalaran pada pola dan sifat, melakukan manipulasi matematika dalam membuat generalisasi, menyusun bukti, atau menjelaskan gagasan dan pernyataan matematika.

3. Memecahkan masalah yang meliputi kemampuan

${ }^{1}$ Corresponding Author: Meli Rama Yunita

Program Magister Pendidikan Matematika, Universitas Negeri Medan, Medan, 20221, Indonesia

E-mail: meliramayunita22@gmail.com

${ }^{2}$ Co-Author: Edy Surya \& Edi Syahputra

Program Studi Pendidikan Matematika, Universitas Negeri Medan, Medan, 20221, Indonesia memahami masalah, merancang model matematika, menyelesaikan model dan menafsirkan solusi yang diperoleh.

4. Mengomunikasikan gagasan dengan simbol, tabel, diagram, atau media lain untuk memperjelas keadaan atau masalah.

5. Memiliki sikap menghargai kegunaan matematika dalam kehidupan, yaitu memiliki rasa ingin tahu, perhatian, dan minat dalam mempelajari matematika, serta sikap ulet dan percaya diri dalam pemecahan masalah.

Pentingnya penguasaan matematika bagi peserta didik tidak sejalan dengan kualitas penguasaan atas matematika. Namun pada kenyataannya banyak siswa yang mengalami kesulitan dalam belajar matematika, kurang berminat dan selalu menganggap matematika sebagai pelajaran yang sukar, sehingga menimbulkan rasa takut untuk belajar matematika yang menyebabkan rendahnya hasil belajar. Hasil belajar matematika siswa sampai saat ini masih jauh yang diharapkan seperti yang diungkapkan hasratuddin (2013:119) bahwa di lihat dari hasil belajar matematika siswa tingkat sekolah Dasar sampai Sekolah Lanjut Tingkat Atas selalu dibawah bidang studi lain.

Agar proses pembelajaran mencapai tujuan pembelajaran yang diharapkan, perlu adanya pengembangan perangkat pembelajaran yang sesuai dengan model atau pendekatan yang diterapkan. Dalam pengembangan perangkat pembelajaran, penyusunan perangkat pembelajaran hendaknya dapat memudahkan siswa dalam memahami materi. Guru sebagai pelaksana pendidikan diharuskan memiliki perangkat dalam

Pengembangan Perangkat Pembelajaran Berbasis masalah untuk Meningkatkan Kemampuan Visual Thinking dan Self-Efficacy Siswa Kelas VII SMP Swasta raja Garuda MAS Besitang 
pelaksanaan pembelajaran untuk menjaga tujuan umum dan tujuan khusus agar proses pendidikan berjalan sesuai dengan yang diharapkan pemerintah

Menurut Sodijarto (dalam Wiyana, 2013: 240), kemampuan profesional guru meliputi: “(1) merancang dan merencanakan program pembelajaran, (2) mengembangkan program pembelajaran, (3) mengelola pelaksanaan program pembelajaran, (4) menilai proses dan hasil pembelajaran, (5) mendiagnosis faktor yang mempengaruhi keberhasilan proses pembelajaran. Kemampuan profesional tersebut merupakan bagian dari kompetensi yang dimiliki guru. Hal yang sama juga disampaikan dalam jurnalnya Sapta, Hamid, Syahputra (2018:1) Pembelajaran yang diinginkan guru tidak lagi dominan, tetapi lebih ditekankan pada interaksi dua arah antara guru dan siswa. Proses pembelajaran akan lebih baik jika ada yang lebih nyata interaksi antara siswa dan guru. Diharapkan juga bahwa guru dapat mendesain yang ada belajar sejak usia dini dengan lingkungan di lingkungan pendidikan untuk mencapai tujuan pembelajaran.

Pengembangan perangkat pembelajaran adalah serangkaian proses atau kegiatan yang dilakukan untuk menghasilkan suatu perangkat pembelajaran berdasarkan teori pengembangan yang telah ada (Rohman dan Amri, 2013:207). Jadi pengembangan perangkat pembelajaran adalah suatu proses yang dilakukan untuk menghasilkan serangkaian perangkat pembelajaran yang digunakan oleh guru dan siswa dalam proses pembelajaran di kelas. Serangkaian perangkat pembelajaran yang harus dipersiapkan seorang guru dalam menghadapi pembelajaran di kelas, antara lain: (a) Rencana Pelaksanaan Pembelajaran (RPP); (b) Buku Siswa; (c) Buku guru (BG); (d) Lembar Aktivitas Siswa (LAS); (e) Tes kemampuan belajar. Semua mata pelajaran dapat dikembangkan perangkat pembelajarannya, tidak terkecuali matematika.

Matematika terbentuk dari pengalaman manusia dalam dunianya secara empiris. Kemudian pengalaman itu diproses di dalam dunia rasio, diolah secara analisis dengan penalaran di dalam struktur kognitif sehingga sampai terbentuk konsep-konsep matematika supaya konsep-konsep matematika yang terbentuk itu mudah dipahami oleh orang lain dan dapat dimanipulasi secara tepat, maka digunakan bahasa matematika atau notasi matematika yang bernilai global (universal). Konsep matematika didapat karena proses berpikir, karena itu logika adalah dasar terbentuknya matematika. Namun demikian pada kenyataannya pembelajaran matematika di Indonesia masih kalah bersaing dalam dunia internasional. Hal ini ditunjukkan dengan hasil studi PISA (Program for International Student Assessment) tahun 2015 yang menunjukkan Indonesia baru bisa menduduki peringkat 69 dari 76 negara (Ramadanti :2016).

Menurut Hosnan (2014: 31) proses pembelajaran di kelas masih kurang mendapatkan perhatian. Belum semua guru melakukan inovasi pada kegiatan inti pembelajaran. Hal ini menyebabkan pembelajaran masih kurang diminati oleh siswa, sehingga siswa merasa tidak terlalu antusias belajar matematika.
Perangkat pembelajaran yang digunakan untuk mencapai tujuan pembelajaran yang direncanakan hendaknya dikembangkan sesuai dengan kebutuhan siswa. Perangkat yang dikembangkan berorientasi pada model pembelajaran berbasis masalah yang dapat memfasilitasi siswa untuk meningkatkan kemampuan berfikir siswa, mengaktifkan siswa untuk belajar, memberikan kesempatan siswa untuk membangun pengetahuannya sendiri, pembelajaran yang berpusat pada siswa dan disesuaikan dengan tujuan yang akan dicapai.

Penggunaan masalah-masalah kontekstual dalam model pembelajaran berbasis masalah menjadikan pembelajaran tersebut lebih bermakna. Surya dan Syahputra (2017) menyampaikan bahwa dalam pembelajaran berbasis masalah (PBL) menggambarkan lingkungan belajar di mana masalah mendorong pembelajaran, belajar dimulai dengan masalah yang harus dipecahkan, dan masalah yang diajukan sedemikian rupa sehingga siswa perlu mendapatkan pengtahuan baru sebelum mereka bisa menyelesaikan masalah dengan mencari satu jawaban benar, siswa menginterpretasikan masalah, mengumpulkan informasi yang diperlukan, mengidentifikasi solusi yang mungkin, mengevaluasi opsi, dan menyajikan kesimpulan.

Menurut Muslimin (dalam Boud 2000:7), Pembelajaran berdasarkan masalah adalah suatu pendekatan untuk membelajarkan siswa untuk mengembangkan keterampilan berfikir dan keterampilan memecahkan masalah, belajar peranan orang dewasa yang otentik serta menjadi pelajar mandiri. Pembelajaran berdasarkan masalah tidak dirancang untuk membantu guru memberikan informasi yang sebanyak-banyaknya kepada siswa, akan tetapi pembelajaran berbasis masalah dikembangkan untuk membantu siswa mengembangkan kemampuan berpikir, pemecahan masalah dan keterampilan intelektual, belajar berbagai peran orang dewasa melalui pelibatan mereka dalam pengalaman nyata dan menjadi pembelajaran yang mandiri.

Berdasarkan pendapat-pendapat tersebut diatas dapat diambil beberapa hal penting terkait pembelajaran berbasis masalah yaitu, 1) memberi ruang gerak yang lebih bebas kepada anak untuk menggali kemampuan berfikir untuk menemukan konsep, 2) efektif digunakan untuk pengembangan kemampuan berfikir siswa, 3) membangkitkan minat dan membuat siswa memiliki fokus yang lebih baik dalam memahami dan meningkatkan kinerja siswa, 4) kegiatan kolaboratif siswa dan aktivitas siswa didalam kelas terlihat lebih baik dan memungkinkan terjadinya interaksi yang dinamis antara guru dengan siswa, siswa dengan siswa, 5) meningkatkan motivasi siswa dan kepercayan diri dalam belajar, kemampuan kritis dan kerja tim.

Representasi visual menjadi bagian yang penting dalam menyelesaikan masalah matematik. Lavy (Surya, 2013:113) menyampaikan pentingnya visualisasi dalam memecahkan masalah matematika.

Visualization has an important role in thinking development, mathematical comprehension, and the transition thinking of concrete to abstract thinking related to mathematical problem solving. 


\section{PARADIKMA JURNAL PENDIDIKAN MATEMATIKA}

Vol. 13, No. 2, Desember 2020

Visualisasi memiliki peran penting dalam pengembangan berpikir, pemahaman matematika, dan transisi pemikiran untuk pemikiran abstrak yang berkaitan dengan pemecahan masalah matematika.

Dalam pembelajaran matematika dibutuhkan kemampuan untuk berfikir visual (visual thinking). Berpikir visual (Visual Thinking) dapat menjadi salah satu alternatif untuk mempermudah siswa dalam mempelajari matematika. Hal ini sejalan dengan apa yang dikemukan oleh Surya (Ariawan, 2016:23) yang menyatakan bahwa siswa biasanya mengalami kesulitan menjembatani pengetahuan informal ke matematika sekolah. Siswa perlu bimbingan dan bantuan khusus pada bentuk representasi pemikiran visual (Visual Thinking) dari apa yang mereka maksud atau mereka pikirkan sehingga dapat divisualisasikan dalam bentuk struktur ide, ide tersebut bisa sebagai angka, simbol, gambar, diagram, penjelasan model, lukisan yang dapat membantu siswa dalam proses belajar dan menyelesaikan permasalahan matematika mereka.

Menurut Surya (2013) Visual Thinking adalah suatu pemikiran yang aktif dan proses analitis untuk memahami, menafsirkan dan memproduksi pesan visual, interaksi antara melihat, membayangkan, dan menggambarkan sebagai tujuan dan dapat digunakan, seperti berpikir verbal.

Untuk membantu siswa mengembangkan kemampuan visualisasi (visual thinking), guru harus terlebih dahulu memperhatikan faktor-faktor yang mempengaruhi pilihan siswa dalam metode pemecahan masalah dari proses dan peran yang digunakan siswa dalam visualisasi di pemecahan masalah matematika. Jika visualisasi adalah inti pemecahan masalah matematika maka sangat penting bahwa baik guru dan siswa melihat peran visualisasi dan menggunakannya membantu mereka dalam proses mereka memecahkan masalah.

Jika kemampuan visual thinking matematis dimiliki oleh siswa, tentu siswa akan mudah untuk merepresentasikan masalah dan menyelesaikan masalah matematika, merepresentasikan masalah matematika baik kedalam bentuk gambar, grafik, tabel, simbol, pola ,persamaan matematika dan lain sebagainya. namun kenyataannya kemampuan representasi visual thinking siswa masih rendah. Ini bisa dilihat dari observasi yang dilakukan peneliti. Peneliti mengajukan masalah kepada siswa SMP Swasta Raja Garuda Mas Besitang.

Masalah yang diajukan kepada siswa adalah sebagai berikut.

Sebuah model kerangka balok terbuat dari kawat dengan ukuran panjang $(x+5)$ dan lebar $(x-2) \mathrm{cm}$ dan tingginya $x$ $\mathrm{cm}$. panjang kawat yang di gunakan seluruhnya tidak boleh dari $156 \mathrm{~cm}$.

1)Tuliskan apa yang di ketahui dalam masalah diatas?

2)Susunlah pertidaksamaan dalam bentuk $x$

3) Tentukan Nilai $x$

Peneliti melakukan percobaan pertama dengan memberikan soal diatas kepada 28 orang siswa kelas VIII SMP Swasta Raja Garuda Mas Besitang. Siswa kelas VIII ini sudah mendapatkan materi bangun datar dan persamaan linear satu variabel dikelas VIII. Namun hanya
3 orang siswa yang memenuhi dan dapat merepresentasikan hasil visualisasi sesuai dengan harapan peneliti dan selainnya belum dapat memvisualisasikan dan merepresentasikannya dengan benar. Berikut jawaban siswa.

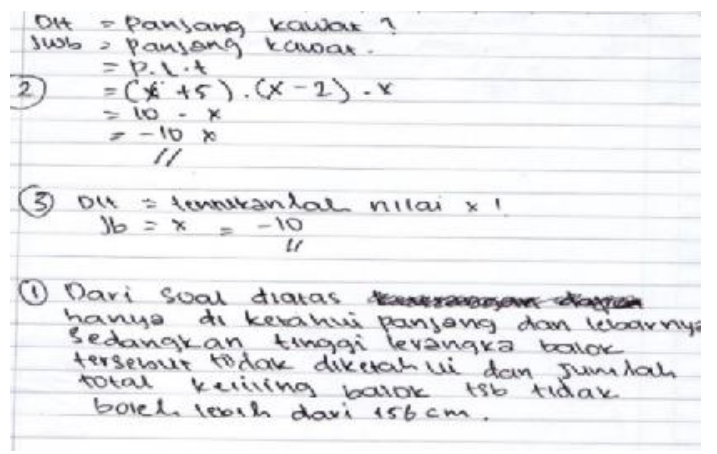

Gambar 1. Jawaban Siswa pada soal Representasi Visual Thinking

Dari gambar diatas menunjukkan siswa Siswa tidak memahami permasalahan pada soal yang diberikan, tidak mampu mengaitkan antara yang ditanya dengan alternatif permasalahan, Siswa tidak memahami masalah, sehingga tidak mampu membuat model pertidaksamaa matematika sehingga siswa tidak bisa merepresentasikan masalaha dengan benar. Siswa akan dapat menyelesaikan soal diatas bila ia mampu memahami masalah dengan menuliskan apa yang diketahui pada soal sehingga akan memudahkan siswa dalam memahami masalah, memvisualisasikan masalah dalam bentuk persamaan linear dan mengaitkanya dalam bentuk pertidaksamaan linear satu variabel. Setelah siswa sudah mampu mengebuh masalah kedalam persamaan matematika siswa dapat mencari nilai dari x. Setiap individu mungkin akan berbeda-beda dalam memvisualisasikan. Dari sinilah kita akan mengetahui kemampuan visualisasi seorang siswa pada tingkatan itu. Dari percobaan yang dilakukan peneliti menunjukkan rendahnya kemampuan representasi visual thinking siswa

Selain kemampuan representasi visual thinking matematis. Kemampuan self efficacy siswa juga penting. Individu dengan self-efficacy tinggi memiliki komitmen dalam memecahkan masalah dan tidak akan menyerah ketika menemukan bahwa strategi yang diberikan tidak berhasil. Menurut Bandura(1997:131), Individu yang memiliki efikasi diri yang tinggi akan sangat mudah dalam menghadapi tantangan, individu tidak merasa ragu karena iya memiliki kepercayaan yang penuh dengan kemampuan drinya. Sehingga dapat dikatakan bahwa individu dengan self- efficacy yang tinggi juga memiliki kemampuan berfikir kritis.

Bandura (2006:24) mendefinisikan Self-efficacy sebagai keyakinan orang tentang kemampuan mereka untuk menghasilkan tingkat kinerja yang ditunjuk sebagai latihan atas peristiwa yang mempengaruhi kehidupan mereka. Kemampuan tersebut diukur berdasarkan level (tingkat kesulitan masalah), strength (ketahanan) dalam menyelesaikan masalah, generality (keluasan) dalam masalah yang diberikan. 
Vol. 13, No. 2, Desember 2020

Mengingat pentingnya self- efficacy siswa, maka hendaknya self-efficacy ditumbuhkembangkan pada diri siswa. Ketercapaian self- efficacy matematika siswa dapat diketahui dengan melakukan observasi dan wawancara pada proses pembelajaran matematika dan skala self- efficacy, disini peneliti melihat ketercapaian self- efficacy dalam penelitian ini diartikan sebagai kepercayaan diri siswa terhadap kemampuannya dalam merepresentasikan dan memecahkan dalam suatu masalah matematika. Artinya ketika siswa siswa diberikan suatu masalah ia dapat menyatakan atau meyakini dirinya tentang kemampuanya dalam menyelesaikan masalah tersebut. Namun fakta membuktikan self-efficacy siswa masih rendah ini dapat dilihat dari data observasi dan wawancara dengan guru mata pelajaran matematika yang mengajar di SMP Swasta Raja Garuda Mas Besitang mengemukakan, Beliau mengemukakan kemampuan self efficacy siswa masih rendah ini dapat terlihat ketika mengerjakan soal latihan siswa lebih cepat menyerah ketika dihadapkan oleh permasalahan yang sulit, disamping itu siswa juga tidak yakin dengan jawaban yang diperolehnya, dan ketika salah satu temanya mempresentasikan jawaban didepan kelas siswa yang lain enggan menanngapi permasalahan dikarenakan ragu akan kemampuan diri yang dimiliki. Hal ini semua mengindikasikan kemampuan self efficacy siswa rendah.

Berdasarkan uraian di atas, peneliti tertarik untuk melakukan penelitian berjudul “ Pengembangan Perangkat Pembelajaran Berbasis Masalah untuk Meningkatkan Kemampuan Visual Thinking matematis dan Self Efficacy siswa Kelas VII SMP Swasta Raja Garuda Mas".

\section{KAJIAN TEORITIS}

Menurut Goldin (2002: 209) representasi adalah suatu konfigurasi (bentuk atau susunan yang dapat menggambarkan, mewakili, atau melambangkan sesuatu dalam suatu cara. Contohnya, suatu kata dapat menggambarkan suatu objek kehidupan nyata atau suatu angka dapat mewakili suatu posisi dalam garis bilangan. Dalam hal ini, hubungan representasi- representasi dapat dipandang sebagai hubungan dua arah (bidirectional) yaitu representasi eksternal dan representasi internal. Representasi internal merupakan sistem representasi psikologis dari individu -individu itu sendiri seperti bahasa ibu yang digunakan, perbandingan visual dan spasial, dan seterusnya. Pada dasarnya representasi internal tidak dapat dilihat secara kasat mata, hanya bisa dipertanyakan pada inidividu-individu yang bersangkutan, sedangkan representasi ekstrnal merupakan representasi fisik dalam bentuk bahasa lisan, bahasa tertulis, simbol gambar atau objek fisik.

Hiebert dan Wearne dalam Mulligan, Mitchelmore, Outhred, dan Bobis (2002) memandang bahwa pemahaman konsepyang dibangun dalam pengonstruksian pemikiran akan menghubungkan beberapa representasi ide-ide matematik secara fisik, gambar, verbal, dan simbol. Lebih jauh, Hiebert dan Wearne memberi kesan bahwa pembangunan Hubungan-hubungan antara representasi eksternal akan mendorong tumbuhnya pemahaman konsep dan representasi internal yang lebih terpadu dari ide-ide matematik.

Berdasarkan paparan diatas dapat disimpulkan bahwa prosesberv visual thinking atau representasi visual dapat dilihat dari dua interaksi representasi internal dan eksternal terjadi secara timbal balik (feedback) ketika seseorang mempelajari matematika, secara visual dapat di representasikan dalam bentuk gambar Interaksi Representasi Visual Thinking sebagai berikut:

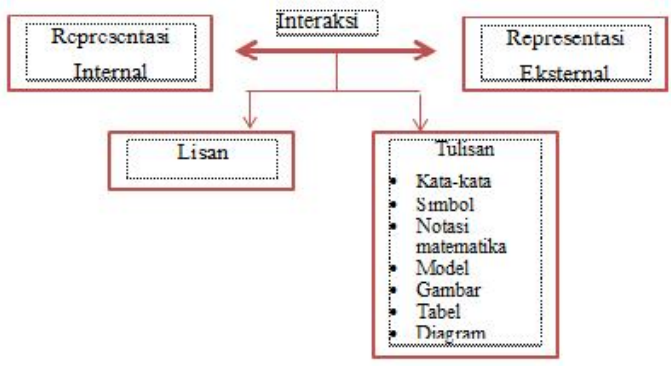

Gambar 2. Interaksi Representasi Visual Thinking

Dengan demikian, dari gambar 1 jika siswa memiliki kemampuan interaksi tersebut siswa lebih mudah memandang permasalahan dalam bentuk sederhana dan lebih mudah memvisualisasikan permasalahan dalam bentuk lisan maupun tulisan. Siswa memiliki kemampuan keterampilan komunikasi matematik. Hal ini disebabkan representasi-representasi tersebut membantu siswa untuk mengorganisasikan kemampuan visual thinking dalam memvisualisasikan masalah dengan menggunakan pemahamannya serta memfokuskan padahal-hal yang esensial dari masalah yang dihadapinya. Mengkonstruk permasalahan dalam bentuk kata-kata, simbol, notasi matematika, model matematika, gambar, tabel, diagram.

\begin{tabular}{|c|c|}
\hline Indikator & Aspek \\
\hline $\begin{array}{l}\text { 1. Melihat stan memshami } \\
\text { masslah }\end{array}$ & $\begin{array}{l}\text { Mengidentifikasi / memahami masalah } \\
\text { dengan menterjemahksan informasi } \\
\text { yang diketahui dan ditanya dengan } \\
\text { merepresentasikan dalam bentuk visual } \\
\text { ( diagram, gamber, tabel atsn pola, } \\
\text { elsapresi matematiks/persamaan } \\
\text { matematika, model matematika dan lain } \\
\text { sabagainya) atan verbal. }\end{array}$ \\
\hline $\begin{array}{l}\text { 2. Mampu merencanalkan dan } \\
\text { menyelesaikan masalsh dalam } \\
\text { bentuk visual atan verbal. }\end{array}$ & $\begin{array}{l}\text { Mengelsatrak informasi tertentu dengan } \\
\text { memrepresentasikan dan menafsirkan } \\
\text { masalah dari visual (diagram, gambar, } \\
\text { tabel atsu pola, elkspresi } \\
\text { matematiks persamaen matematika, } \\
\text { model matematika dan lain sabagainya) } \\
\text { atan verbal. Untuk merencanakan dan } \\
\text { menyelesaikan masalah }\end{array}$ \\
\hline 3. Memeriksa dan menyimpulkan & $\begin{array}{l}\text { Mampu memeriksa solusi jawaban dari } \\
\text { permasalahan dan mampu menjelaskan } \\
\text { atsu menyimpulkan apa yang diperoleh } \\
\text { dari hasil pemecahan masalah sacra } \\
\text { jelsa dengan cara mengkomunikasikan } \\
\text { masalah dalam bentuk verbal atsu non } \\
\text { verbal. }\end{array}$ \\
\hline
\end{tabular}

Gambar 3. Indikator Kemampuan Visual Thinking Matematis.

Menurut Bandura (1999:2) bahwa self efficacy refers to beliefs in one's capabilities to organize and execute the courses of action required to manage prospective situations. Efficacy beliefs influence how people think, feel, motivate them selves, and act". Maksudnya adalah self-efficacy mengacu pada keyakinan dalam kemampuan seseorang untuk mengorganisasikan dan melaksanakan

Pengembangan Perangkat Pembelajaran Berbasis masalah untuk Meningkatkan Kemampuan Visual Thinking dan Self-Efficacy Siswa Kelas VII SMP Swasta raja Garuda MAS Besitang 
serangkaian tindakan yang dibutuhkan untuk mengelola situasi yang prospektif. Keyakinan tersebut mempengaruhi bagaimana orang berpikir, merasa, memotivasi diri, dan bertindak. Bandura merupakan tokoh aliran psikologi sosial yang tulisannya banyak mengulas tentang self-efficacy, beliau memberikan pengertian sel-efficacy masih bersifat umum. Ungkapan 'situasi tertentu' bermakna luas, karena memang selfefficacy ini dibutuhkan dalam segala bidang, termasuk dalam pembelajaran matematika, dan yang lebih khusus lagi dalam situasi siswa menghadapi dan memecahkan masalah matematika. Huda (2013: 59) mengatakan "yang harus dilakukanoleh guru adalah mengembangkan lingkungan belajar dimana semua siswa dapat mengembangkan kemajuan diri dan motivasinya untuk beraktivitas. Self-efficacy yang terbentuk akan mempengaruhi dan memberikan fungsi pada aktivitas individu

Menurut Bandura (1997) pengukuran self-efficacy yang dimilki seseorang mengacu pada tiga dimensi, yaitu: a. Level (tingkat kesulitan masalah). Indiktor yang berkaitan dengan tingkat kesulitan masalah yang diberikan. Kemampuan seseorang menyelesaikan masalah dengan tingkatan kesulitan berbeda. Individu dengan self-efficacy tinggi akan mempunyai keyakinan yang tinggi tentang kemampuan memecahkan masalah matematik yang sulit, sebaliknya individu yang memiliki self-efficacy rendah akan memiliki keyakinan yang rendah pula tentang kemampuan dalam memecahkan masalah matematik yang dianggapnya sulit. Individu akan berupaya memecahkan masalah yang ia persepsikan dapat ia selesaikan, dan ia akan menghindari masalah yang ia persepsikan diluar batas kemampuannya.

b. Strength (ketahanan), indikator ini berkaitan dengana kekuatan pada keyakinan atas kemampuannya, atau suatu kepercayaan diri yang ada dalam diri seseorang yang dapat ia wujudkan dalam meraih performa tertentu. Individu memiliki keyakinan yang kuat menyelesaikan masalah matematik yang dihadapinya, meskipun masalah tersebut sulit. Semakin kuat selfefficacy maka semakin besar ketekunan, sehingga semakin tinggi kemungkinan masalah yang dipilihnya untuk dipecahkan.

c. Generality (keluasan), indikator self-efficacy berkaitan dengan cakupan luas bidang tingkah laku di mana individu merasan yakin terhadap kemampuannya. Individu mampu menilai keyakinan dirinya menyelesaikan masalah matematik yang diberikan diberbagai materi atau dalam materi tertentu saja. Mampu tidaknya seseorang menyelesaikan masalah matematik pada materi tertentu ataupun berbagai materi mengungkapkan gambaran secara umum tentang self-efficacy individu tersebut.

Untuk meningkatkan self-efficacy siswa, ada beberapa strategi yang dapat kita lakukan yaitu :

a. Mengajarkan siswa dengan pendekatan khusus sehingga dapat meningkatkan kemampuannya untuk fokus pada tugas-tugasnya. b. Memandu siswa dalam menetapkan tujuan, khususnya dalam membuat tujuan jangka pendek setelah mereka mebuat tujuan jangka panjang.

c. Memberikan reward untuk performa siswa.

d. Mengkombinasikan strategi training dengan menekankan pada tujuan dan memberi umpan balik pada siswa tentang hasil pembelajarannya.

e. Memberikan support atau dukungan pada siswa. Dukungan yang positif dapat berasal dari guru seperti pernyataan "kamu dapat melakukan ini", dan lain-lain.

f. Meyakinkan bahwa siswa tidak terlalu cemas karena hal itu justru akan menurunkan self-efficacy siswa.

g. Menyediakan siswa model yang bersifat positif seperti teman sebaya dan orang dewasa. Karakteristik tertentu dari model dapat meningkatkan self-efficacy siswa. Modelling efektif untuk meningkatkan self-efficacy khususnya ketika siswa mengobservasi keberhasilan teman sebayanya yang sebenarnya mempunyai kemampuan yang sama dengan mereka .

Berdasarkan ungkapan di atas, pengertian dari selfefficacy matematika dalam penelitian ini merupakan kepercayaan diri seseorang terhadap; kemampuannya dalam merepresentasikan, menyelesaikan masalah matematika yang dihadapinya dalam proses pembelajaran matematika di kelas sehingga tercapailah tujuan yang diinginkan yang diukur berdasarkan dimensi level (tingkat kesulitan masalah), Strength (ketahanan), Generality (keluasan).

\section{Model Pembelajaran Berbasis Masalah (Promblem Basaed Learning)}

Peran guru dalam pengajaran berbasis masalah adalah menyajikan masalah, mengajukan pertanyaan, dan memfasilitasi penyelidikan dan dialog, disamping itu guru memberikan dukungan (scaffolding) dan dorongan yang dapat meningkatkan pertumbuhan inquiry (penyelidikan dan kemampuan intelektual siswa (Arends,2008:47). Pada pembelajaran berbasis masalah terdiri dari 5 (lima) langkah utama yang dimulai dengan guru memperkenalkan siswa dengan situasi masalah dan diakhiri dengan penyajian dan analisis hasil kerja siswa.

\section{METODE PENELITIAN}

Penelitian ini dikategorikan ke dalam jenis Penelitian Pengembangan (Development Research). Model pengembangan perangkat pembelajaran dalam penelitian ini dengan menggunakan 4D Thiagarajan, Sammel \& Sammel (1974). Perangkat pembelajaran yang dikembangkan berorientasi pada pembelajaran berbasis masalah pada materi persamaan linear satu variabel dikelas VII SMP. Perangkat pembelajaran yang dikembangkan meliputi buku siswa, buku guru, rencana pelaksanaan pembelajaran (RPP) dan lembar kerja siswa (LKS). Selain itu dalam penelitian ini akan disusun instrumen kemampuan visual thinking angket kemampuan self efficacy, lembar validasi, lembar observasi, dan angket.

Penelitian ini dibagi dalam dua tahap, tahap pertama adalah pengembangan perangkat pembelajaran. Pengembangan perangkat pembelajaran yang meliputi: (1) validitas Buku Guru ; (2) validitas Buku Siswa ; (3) validitas LAS; (4) validitas instrumen tes kemampuan 
Vol. 13, No. 2, Desember 2020

\begin{abstract}
Representasi Visual Thingking. Tahap kedua adalah implementasi perangkat pembelajaran yang sudah divalidasi untuk melihat kepraktisan dan keefektifannya.

Model pengembangan yang digunakan untuk mengembangkan perangkat pembelajaran dalam penelitian ini adalah modifikasi dari model Thiagarajan, Semmel dan Semmel yang dikenal dengan model 4-D (Four D Mode) yang terdiri dari 4 tahap pengembangan yaitu tahap pendefinisian (define), perancangan (design), pengembangan (develop) dan penyebaran (disseminate) (Trianto, 2007:56). Gambar model pengembangan Thiagarajan Semmel dan Semmel
\end{abstract}

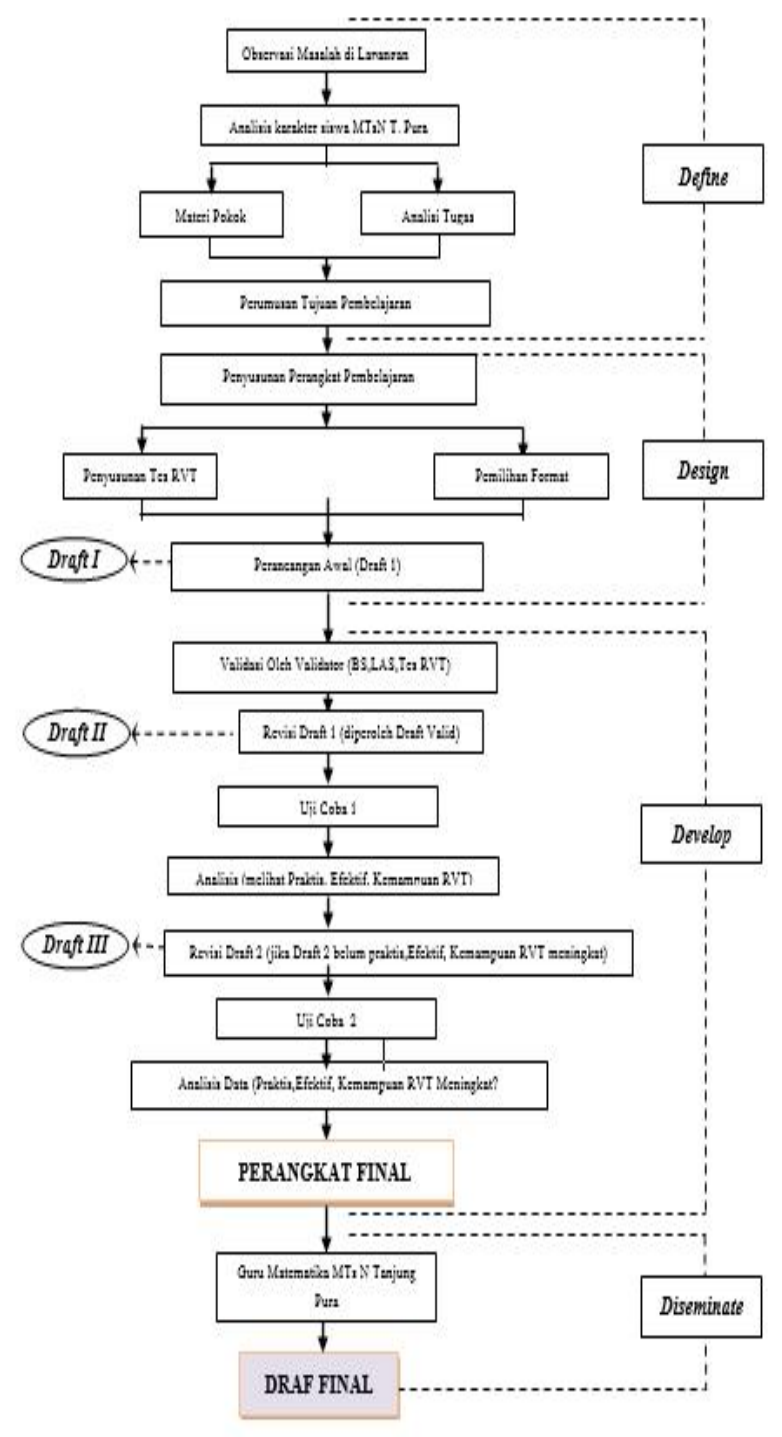

Gambar 5. Bagan pengembangan perangkat pembelajaran model 4-D (Trianto, 2011)

Rancangan uji coba yang akan digunakan dalam pengembangan instrument adalah One - group pretes postes design. Sebagai berikut :

\begin{tabular}{|lcl|}
\hline Tes & Perlakuan & Tes \\
$\mathrm{T}$ & $\mathrm{x}$ & $\mathrm{T}$ \\
\hline
\end{tabular}

\section{Keterangan :}

$\mathrm{T}_{1}=$ Pre - tes

$\mathrm{T}_{2}=$ Post - tes

$\mathrm{X}=$ Perlakuan pelajaran berbasis pendekatan kontekstual.

Tempat dan Waktu Penelitian

Penelitian ini dilaksanakan di SMP Swasta Raja

Garuda mas Besitang, kelas VII pada Tahun Pelajaran 2016/2017, dengan jadwal yang dikoordinasikan dengan kegiatan sekolah yang dilaksanakan pada bulan November- Desember tahun 2017. Adapun alasan penelitian memilih sekolah tersebut adalah: 1) Hasil penelitian pendahuluan/observasi awal menunjukkan bahwa kemampuan visual thinking matematis dan kemampuan self efficacy siswa dikelas VII masih rendah, 2) Belum pernah ada penelitian yang sejenis dilakukan di sekolah tersebut, 3) Sekolah tersebut sangat terbuka bagi peneliti yang ingin memperbaiki proses pembelajaran

\section{Subjek Penelitian dan Objek Penelitian}

Subjek penelitian ini adalah siswa kelas VII SMP Swasta Raja Garuda Mas Besitang. Sedangkan objek dalam penelitian ini adalah perangkat pembelajaran matematika SMP kelas VII berbasis masalah yang dikembangkan. Perangkat pembelajaran yang dikembangkan dalam penelitian ini yaitu materi persaman dan pertidaksamaan linear satu variabel.

Peneliti memilih subjek siswa kelas VII SMP Swasta Raja Garuda Mas Besitang dan objek dari penelitian ini adalah perangkat pembelajaran matematika SMP kelas VII berbasis masalah yang dikembangkan, karena di SMP Swasta Raja Garuda Mas Besitang belum pernah dilakukan penelitian terkait dengan pengembangan perangkat pembelajaran berbasis masalah pada materi persaman dan pertidaksamaan linear satu variabel khususnya untuk meningkatkan kemampuan visual thinking matematis dan kemampuan self efficacy siswa.

\section{HASIL PENELITIAN}

Pada tahap pendefinisian, dilaksanakan lima analisis, yaitu (1) Analisis awal akhir; (2) Analisis siswa; (3) Analisis konsep;(4) Analisis tugas;(5) Perumusan tujuan pembelajaran. Hasil dari setiap kegiatan pada tahap pendefinisian (define) diuraikan sebagai berikut.

\section{1) Analisis Awal - Akhir (Front-End Analysis}

Berdasarkan hasil observasi terhadap perangkat pembelajaran di SMP Swasta Raja Garuda Mas Besitang ditemukan beberapa kelemahan pada perangkat pembelajaran yang digunakan oleh guru dimana secara tidak langsung menjadi salah satu faktor rendahnya kemampuan visual thinking dan self efficacy siswa. Kelemahan perangkat pembelajaran dimulai dari RPP yang digunakan guru memperlihatkan bahwa guru masih menjadi pusat belajar karena belum adanya penggunaan model pembelajaran yang tepat. RPP juga belum mengukur kemampuan matematis siswa salah satunya kemampuan visual thinking matematis. Selain itu self efficacy siswa juga rendah sebab jarangnya proses pembelajaran dilaksanakan secara menarik dan menyenangkan.

Untuk mencapai tujuan pembelajaran yang telah di rumuskan perangkat pembelajaran harus mengacu pada

Pengembangan Perangkat Pembelajaran Berbasis masalah untuk Meningkatkan Kemampuan Visual Thinking dan Self-Efficacy Siswa Kelas VII SMP Swasta raja Garuda MAS Besitang 
Vol. 13, No. 2, Desember 2020

suatu model pembelajaran. Pada penelitian ini perangkat pembelajaran yang dikembangkan berfokus pada peningkatan kemampuan visual thinking dan self efficacy siswa. Salah satu model pembelajaran yang menekankan meningkatkan kemampuan visual thinking dan self efficacy siswa adalah pembelajaran berbasis masalah.untuk mencapai tujuan pembelajaran yang ditetapkan dikembangkan suatu perangkat pembelajaran yang baik. Perangkat yang dikembangkan berupa, RPP, Buku Guru, Buku Siswa, LKS dan Tes Kemampuan Visual Thinking.

\section{2) Analisis Siswa (Learner Analysis)}

Karakteristik siswa kelas VII SMP Swasta Raja Garuda Mas Besitang tahun pelajaran 2016/2017 yang ditelaah meliputi latar belakang sosial budaya, motivasi dan pengetahuan siswa. Dilihat dari latar belakang sosial budaya siswa SMP Swasta Raja Garuda Mas Besitang terdiri dari berbagai latar belakang suku dan ras. Walaupun terdiri dari berbagai suku tetapi bahasa yang digunakan dalam kehidupan mereka sehari-hari adalah bahasa Indonesia. Telaah terhadap motivasi belajar siswa diperoleh dari hasil wawancara langsung dengan guru matematika kelas VII SMP Swasta Raja Garuda Mas Besitang yaitu ibu Ramadhani, S.Pd yang menyatakan bahwa motivasi belajar siswa secara intrinsik (dari dalam diri siswa) masih kurang sehingga dipandang perlu adanya upaya peningkatan motivasi belajar walaupun selama ini motivasi secara ekstrinsik tetap diberikan oleh guru.

Telaah terhadap latar belakang pengetahuan siswa, secara umum siswa kelas VII hasil analisis kemampuan awal matematika siswa SMP Swasta RGM Besitang tergolong rendah. Hal ini hasil tes awal yang diberikan kepada siswa kelas VII-1 SMP Swasta Raja Garuda Mas Besitang. Tes awal yang diberiakan menunjukan kemampuan matematika siswa masih tergolong rendah. Dilihat dari sikap siswa diketahui bahwa respon siswa terhadap matematika masih negatif seperti siswa kurang tertarik, tidak percaya diri dan mudah putus asa ketika menyelesaikan masalah matematika. Hasil itu diperoleh dari pemberian angket self efficacy siswa. Selanjutnya dalam proses pembelajaran, siswa mengaku belum pernah mengikuti pembelajaran berbasis masalah dan belajar secara berkelompok dalam kelas hampir jarang dilakukan. Jadi, pembelajaran berbasis masalah masih tergolong baru bagi siswa.

\section{3) Analisis Konsep}

Materi pelajaran yang digunakan dalam penelitian ini adalah materi persamaan dan pertidak samaan linear satu variabel untuk SMP Swasta Raja Garuda Mas Besitang kelas VII dengan mengacu pada Kurikulum 2013. Analisis konsep ini ditujukan untuk mengidentifikasi, merinci, dan menyusun secara sistematis konsep-konsep yang akan dipelajari siswa pada materi Persamaan Linear Satu Variabel Menjadi sebuah peta konsep. Peta konsep ini kemudian disesuaikan dengan pembelajaran berdasarkan model berbasis masalah. Peta konsep yang dihasilkan kemudian dicantumkan pada Buku Siswa (BS) dan Buku Guru (BG). Secara Gambar 1.4. keseluruhan peta konsep yang dihasilkan dalam penelitian ini sebagai berikut:

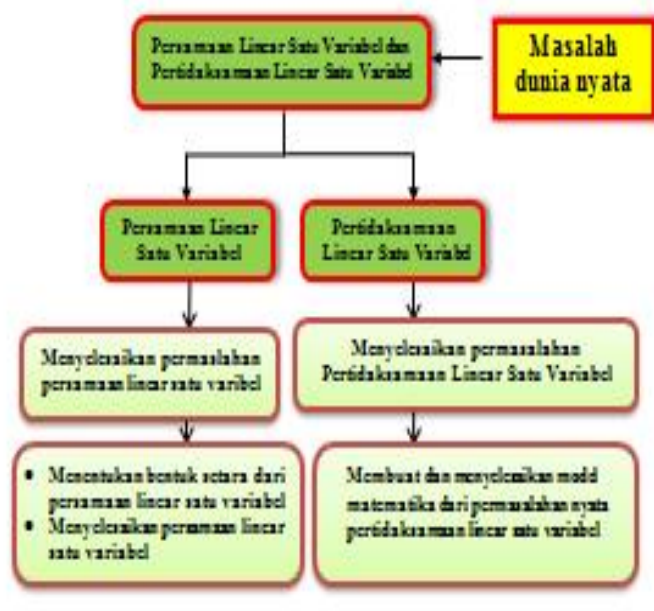

\section{Gambar 6. Peta Konsep}

\section{4) Analisis Tugas}

Analisis tugas ini meliputi tugas umum dan tugas khusus. Tugas umum yang merujuk pada kompetensi inti dan yang telah ditetapkan dalam kurikulum 2013, sedangkan tugas khusus merujuk pada indikator pembelajaran.

\section{5) Perumusan Tujuan Pembelajaran}

Perumusan tujuan pembelajaran diperoleh dengan menjabarkan indikator pencapaian hasil belajar dijabarkan menjadi indikator yang lebih spesifik berupa tujuan pembelajaran dan digabungkan dengan indikator kemampuan visual Thinking dan self efficacy siswa.

\section{Deskripsi Tahap II Perancangan (Design)}

Pada tahap perancangan dilaksanakan empat tahapan yaitu (1) Penyusunan tes dan non tes; (2) Pemilihan media; (3) Pemilihan format; dan (4) Perancangan awal

\section{1) Hasil Penyusunan Tes dan Non Tes}

Tes disusun berdasarkan spesifikasi tujuan pembelajaran dan indikator kemampuan yang diukur. Tes yang disusun untuk mengukur kemampuan visual thinking sedangkan nontes yang di susun yaitu angket self efficacy siswa untuk melihat sikap siswa terhadap pengembangan perangkat yang di kembangkan.

\section{2) Pemilihan Format}

Hasil Pemilihan Format rencana pelaksanaan pembelajaran yang digunakan disesuaikaan dengan format rencana pembelajaran dalam kurikulum 2013.

1. Format RPP yang terdiri dari; kompetensi inti (KI), Kompetensi dasar (KD), Indikator, Tujuan pembelajaran, materi pembelajaran, kegiatan pembelajaran dan sumber pembelajaran, metode, alokasi waktu.

2. Format penyusunan buku (buku petunjuk guru dan buku siswa) mengacu pada aturan BSNP (Badan Standar Nasional Pendidikan)

3. Format LKS mengacu pada model pembelajaran berbasis masalah (PBM).

4. Tes kemampuan visual thinking matematis mengacu pada indikator kemampuan visual thinking matematika.

5. Angket self efficacy mengacu pada format angket tertutup yang berisi butir pertanyaan yang mengacu pada indikator self efficacy siswa. 
Vol. 13, No. 2, Desember 2020

\section{3) Perancangan Awal}

Pada tahap ini, dihasilkan rancangan awal perangkat pembelajaran berupa Rencana Pelaksanaan Pembelajaran (RPP), Buku Guru (BG), Buku Siswa (BS), dan Lembar Kerja Siswa (LKS), untuk 3 kali pertemuan, tes kemampuan visual thinking matematis, pedoman penskoran, serta alternatif jawaban tes. Semua hasil tahap perancangan ini selanjutnya disebut draft I

\section{Deskripsi Tahap III. Pengembangan (Develop)}

Hasil tahap define dan design menghasilkan rancangan awal sebuah perangkat pembelajaran yang disebut dengan draft I. Setelah perangkat pembelajaran berbasis masalah dirancang dalam draft I maka fase pertama pada tahap pengembangan adalah melakukan validasi draft I oleh pakar/ahli (expert review). dan uji coba lapangan. Validasi para ahli difokuskan pada format, isi, ilustrasi, dan bahasa pada perangkat pembelajaran yang dikembangkan. Hasil validasi ahli berupa nilai validasi, koreksi, kritik, dan saran yang digunakan sebagai dasar untuk melakukan revisi dan penyempurnaan perangkat pembelajaran. Perangkat pembelajaran hasil revisi tersebut merupakan perangkat pembelajaran yang telah memenuhi kriteria valid dan selanjutnya disebut draft II. Draf II yang sudah valid akan di uji cobakan pada uji coba 1. Pada uji coba 1 akan dilihat bagaimana keefektifan dan keperaktisan perangkat pembelajaran terhadap perangkat yang dikembangkan dengan menggunakan pembelajaran berbasis masalah. Jika perangkat yang di kembangkan telah memenuhi kriteria efektif dan praktis maka uji coba di hentikan pada uji coba 1, namun jika kriteria efektif dan praktis belum tercapai maka perlu adanya perbaikan terhadap perangkat pembelajaran. Hasil perbaikan perangkat pembelajaran disebut dengan draft III. Draft III akan di uji coba pada uji coba 2. Jika pada uji coba 2 telah memenuhi kriteria efektif dan praktis maka uji coba berhenti pada uji coba 2 .

\section{Tahap IV Penyebaran (Disseminate)}

Pengembangan perangkat pembelajaran mencapai tahap akhir apabila perangkat pembelajaran yang dikembangkan telah memenuhi kreteria valid, efektif dan peraktis. Langkah selanjutnya dilakukan penyebaran terbatas. Peneliti hanya dapat melakukan penyebaran terbatas karena keterbatasan didalam penelitian ini. Penyebaran terbatas yang dilakukan berupa penyerahan bahan final kepada forum MGMP Matematika di SMP Swasta Raja Garuda Mas Besitang. Penyerahan perangkat pembelajaran kepada forum MGMP dengan harapan guru matematika yang tergabung dalam forum tersebut dapat menerapkan perangkat pembelajaran tersebut pada pembelajaran selanjutnya.

\section{PEMBAHASAN}

Deskripsi Kepraktisan Perangkat Pembelajaran pada Uji Coba 1

1. Deskripsi Penilaian Validator Terhadap Perangkat Pembelajaran

Sebelum dilakukannya uji coba peneliti melakukan validasi perangkat pembelajaran. Validasi dilakukan oleh 5 validator untuk melihat tingkat kevalidan suatu perangkat. Hasil validasi dapat dilihat pada gambar 7 berikut.

\begin{tabular}{|r|l|c|c|} 
No & \multicolumn{1}{|c|}{ Ohjek yang Dinilai } & $\begin{array}{c}\text { Nilai Rata-rata } \\
\text { Total Validitas }\end{array}$ & $\begin{array}{c}\text { Tingkat } \\
\text { Validasi }\end{array}$ \\
\hline 1 & Rencana Pelaksanaan Pemhrlajaran (RPP) & 4,56 & Valid \\
$\mathbf{2}$ & Iemhar Krgiatan Siswa (I.KS) & 4,56 & Valid \\
$\mathbf{3}$ & Buku Prtuniuk Guru (BPG) & 4,47 & Valid \\
$\mathbf{4}$ & Buku Siswa (BS) & 4,37 & Valid \\
$\mathbf{5}$ & Trs Krmamyuan Vismnl Thinking & - & Valid \\
\hline
\end{tabular}

Gambar 7. Hasil Validasi

\section{Deskripsi \\ Pembelajaran}

Keterlaksanaan

Perangkat

Keterlaksanaan perangkat pembelajaran yang digunakan ditinjau pada setiap pertemuan. Keterlaksanaan seluruh perangkatn pembelajaran yang digunakan dalam penelitian diamati oleh seorang observer yang merupakan guru bidang studi matematika pada setiap pertemuan yang dilakukan. Adapun rekapitulasi hasil pengamatan terkait keterlaksanaan pembelajaran pada uji coba 1 dapat dilihat pada pada Gambar berikut.

\begin{tabular}{|c|c|c|c|c|c|c|}
\hline \multirow{2}{*}{ No } & \multirow{2}{*}{ Aspek yaug Diamati dan Dinilai } & \multicolumn{3}{|c|}{ Pertemuan } & \multirow{2}{*}{$\begin{array}{c}\text { Rata- } \\
\text { ratas }\end{array}$} & \multirow{2}{*}{$\%$} \\
\hline & & I & II & III & & \\
\hline 1 & $\begin{array}{l}\text { Keterlaksanaan Rencana Pelaksanaan } \\
\text { Pembelajaran (RPP) }\end{array}$ & 3,89 & 4,22 & 4,44 & 4,19 & $83,70 \%$ \\
\hline 2 & $\begin{array}{l}\text { Reterlaksanaan Lembar Aktivitas } \\
\text { Siswa(LAS) }\end{array}$ & 4,00 & 4,00 & 4,50 & 4,17 & $83,33 \%$ \\
\hline 3 & $\begin{array}{l}\text { Keterlaksanaan Buku Petunjul: Guru } \\
\text { (BPG) dan Buku Siswa (BS) }\end{array}$ & 4,20 & 4,00 & 4,00 & 3,87 & $81,33 \%$ \\
\hline & Rata-rata Keterlalssanaan & 4,03 & 4,07 & 4,31 & 4,14 & \multirow{2}{*}{$82,79 \%$} \\
\hline & Persentase Keterlalsanaan & 80,59 & 81,48 & 86,3 & & \\
\hline
\end{tabular}

Gambar 7. Keterlasanaa Perangkat Pembelajaran

Gambar diatas menunjukkan bahwa keterlaksanaan pembelajaran pamenggunakan perangkat yang dikembangkan untuk setiap pertemuan pada uji coba 1 . Keterlaksanaan pembelajaran menggunakan perangkat pembelajaran yang dikembangkan pada pertemuan pertama, mencapai $80,59 \%$. Pada pertemuan kedua mencapai keterlaksanaan $81,48 \%$. Sedangkan pada pertemuan ketiga mencapai keterlaksanaan $86,3 \%$. Untuk lebih jelasnya, keterlaksanaan perangkat pembelajaran untuk setiap pertemuan dan untuk setiap perangkat disajikan pada Gambar 8 berikut.

\section{Keterlaksanaan Setiap Pertemuan}

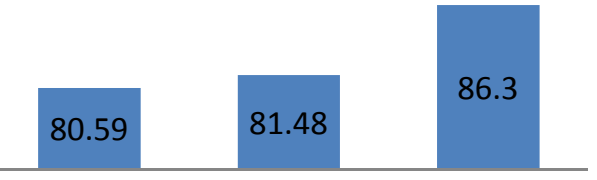

Pertemuan 1 Pertemuan 2 Pertemuan 3

\section{Gambar 8. Keterlasanaa Pertemuan}

Pembelajaran dikatakan berhasil adalah terpenuhinya skor keterlaksanaan pada rentang persentase minimal $80<k<90$ pada kategori "baik". Dengan demikian pada uji coba 1, keterlaksanaan pembelajaran 
Vol. 13, No. 2, Desember 2020

\begin{tabular}{|c|c|c|c|}
\hline $\begin{array}{l}\text { menggunakan perangkat pembelajaran yang } \\
\text { dikembangkan tercapai. } \\
\text { Deskripsi Keefektifan Perangkat Pembelajaran pada }\end{array}$ & Keterangan & Jumlah Siswa & $\begin{array}{l}\text { Prosentase } \\
(\%)\end{array}$ \\
\hline $\begin{array}{l}\text { Uji Coba } 1 \\
\quad \text { Perangkat berorientasi Pembelajaran berbasis masalah }\end{array}$ & Tuntas & 23 & $76,7 \%$ \\
\hline layak digunakan apabila dapat memberikan akibat, efek, & Tidak tuntas & 7 & $23,3 \%$ \\
\hline
\end{tabular}

atau pengaruh yang signifikan terhadap pengguna perangkat pembelajaran ini.Dengan demikian, perangkat pembelajaran yang dikembangkan harus memenuhi kriteria keefektifan. (1) aktivitas aktif siswa memenuhi kriteria pencapaian persentase waktu ideal yang telah ditetapkan. (2) ketuntasan kemampuan representasi visual thinking matematis siswa secara kalsikal, yaitu minimal $80 \%$ siswa yang mengikuti pembelajaran mampu mencapai skor $\geq 2,67$, dan (3) $80 \%$ siswa memberikan respon positif terhadap perangkat pembelajaran.

\section{Analisis Aktivitas Siswa Uji Coba 1}

\begin{tabular}{|c|c|c|c|c|c|}
\hline \multirow{3}{*}{$\begin{array}{l}\text { Pertemuan } \\
\text { I }\left(7 \times 45^{\prime}\right)\end{array}$} & \multicolumn{5}{|c|}{ Perentase Frekuesi Untuk Setiap Jenis Aktivitas } \\
\hline & 1 & 2 & 3 & 4 & 5 \\
\hline & 20.00 & 17.78 & 26.67 & 28.89 & 5.56 \\
\hline II $\left(2 \times 45^{\prime}\right)$ & 23,33 & 16,67 & 31,11 & 25,56 & 4,44 \\
\hline$\pi T\left(2 \times 45^{\prime}\right)$ & 20.00 & 14.44 & 32,22 & 27.78 & 2.22 \\
\hline Rata-rata & 21,11 & 16,30 & 30,00 & 27,41 & 4,07 \\
\hline Kriteria & $\begin{array}{c}20 \% \leq \\
\text { PWI } \leq 3 \mathrm{C} \\
\%\end{array}$ & $\begin{array}{c}10 \% \leq \\
\text { PWI } \leq 2 C \\
\%\end{array}$ & $\begin{array}{c}25 \% \leq \\
\text { PWI } \leq 35 \\
\pi\end{array}$ & $\begin{array}{c}25 \% \leq \\
\mathrm{PWI} \leq 35 \\
\pi, 6\end{array}$ & $\begin{array}{c}0 \% \leq \text { PWI } \\
\leq 3 \%\end{array}$ \\
\hline
\end{tabular}

Gambar 9. Aktivitas Siswa Uji Coba I

Gambar di atas menunjukan presentase rata-rata waktu aktivitas siswa untuk 3 kali pertemuan adalah 21,11\%; $16,30 \% ; 30,00 \% ; 27,41 \%$ dan $4,07 \%$. \%. Rata-rata persentase waktu aktivitassiswa juga disajikan pada Gambar berikut.

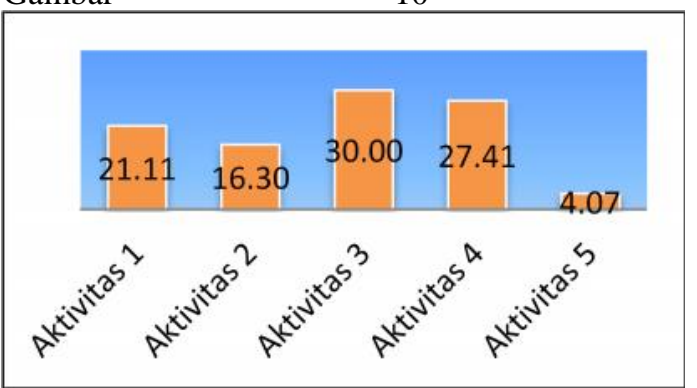

Gambar 11. Aktivitas Siswa

Selanjutnya hasil aktivitas siswa yang diperoleh dirujuk pada kriteria persentase waktu ideal aktivitas siswa yang ditetapkan pada Secara keseluruhan, terdapat 4 kategori (kategori 1, 3, 4 dan 5) yang telah mencapai persentase waktu ideal yang ditetapkan dan terdapat 1 kategori belum memenuhi persentase waktu ideal, yaitu kategori aktivitas membaca buku siswa dan LKS (kategori 2). Itu berari 3 dari 5 kategori (kategori 4 dan 5 terpenuhi) telah mencapai persentase waktu ideal yang ditetapkan. Dengan demikian dapat disimpulkan bahwa perangkat pembelajaran efektif ditinjau dari aktivitas siswa pada uji coba 1 yang sesuai dengan persentase waktu ideal pembelajaran

2. Ketuntasan Kemampuan Representasi Visual

Thinking Matematis Siswa Secara Kalsikal

Hasil ketuntasan pada uji coba 1 dapat disajikan pada tabel 1 dan gambar 12 berikut :

Gambaran presentase Kriteria ketuntasan klasikal kemampuan visual thinking matematis pad a uji coba $1 \mathrm{di}$ sajikan pada gambar 12 berikut.

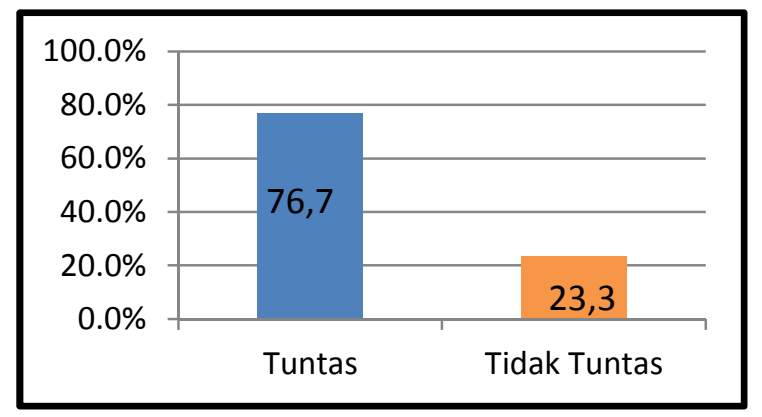

Gambar 11. Presentase Ketuntasan Klasikal kemampuan visual thinking

Berdasarkan Tabel 1 dan Gambar 12 menunjukkan bahwa ketuntasan pos-test kemampuan visual thinking matematis siswa pada uji coba 1 secara klasikal yaitu siswa yang tuntas sebanyak 23 siswa $(76,7 \%)$, sedangkan siswa yang tidak tuntas sebanyak 7 siswa ( 23,3\%) dari 30 siswa yang mengikuti pos-test kemampuan visual thinking matematis. Dari data ini menunjukan bahwa ketuntasan klasikal pada uji coba 1 hanya mencapai $76,7 \%$, ini berarti belum mencapai kriteria ketuntasan secara klasikal sebesar $80 \%$.

\section{Respon Positif}

Analisis angket respon siswa terhadap perangkat pembelajaran yang dikembangkan. Berikut ini akan dijelaskan hasil masing-masing aspek yang terdapat pada angket respon siswa. Hasil analisis data angket respon siswa pada uji coba I disajikan pada Gambar berikut.

\begin{tabular}{|c|c|c|c|}
\hline \multirow[b]{2}{*}{ No } & \multirow[b]{2}{*}{ Aspek } & \multicolumn{2}{|c|}{ \% Rata Rata } \\
\hline & & Senany & $\begin{array}{c}\text { Tidak } \\
\text { Scnang }\end{array}$ \\
\hline 1 & $\begin{array}{l}\text { Perasaan scnang siswa tcrhadap } \\
\text { pcrangkat pembclajaran. }\end{array}$ & $8 / .33$ & 12.61 \\
\hline & & Baru & Tidak Baru \\
\hline \multirow[t]{2}{*}{2} & $\begin{array}{l}\text { Respon siswa terhadap ketaruan } \\
\text { perangkat pembelajaran. }\end{array}$ & 88.57 & 11.33 \\
\hline & & Berminat & $\begin{array}{c}\text { Tidak } \\
\text { Berminat }\end{array}$ \\
\hline 3 & 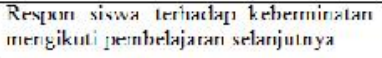 & 86,57 & 13,33 \\
\hline 4 & $\begin{array}{l}\text { Respon siswa terhaciap kejelasan bahasa } \\
\text { yang digunakan pada perangkat } \\
\text { pembelajaran. }\end{array}$ & 86,67 & Tidak \\
\hline & & $\mathbf{Y a}_{\mathbf{a}}$ & Tidak \\
\hline \multirow[t]{2}{*}{5} & $\begin{array}{l}\text { Respon siswa terhadap ketertarikan } \\
\text { pada penampilan } \\
\text { pembelajaran. }\end{array}$ & 88,33 & 11,67 \\
\hline & Kata-rata keseluruhan & 87,78 & 12,22 \\
\hline
\end{tabular}

\section{Gambar 12. Persentase Reson Siswa Uji Coba I}

Dapat dilihat bahwa hasil persentase dari aspek pertama yaitu siswa yang merasa senang terhadap komponen pembelajaran mencapai $87,33 \%$, aspek kedua yaitu siswa yang merasa bahwa komponen perangkat pembelajaran tergolong baru mencapai $88,67 \%$, aspek 
Vol. 13, No. 2, Desember 2020

ketiga yaitu siswa yang merasa berminat dalam mengikuti kegiatan pembelajaran selanjutnya seperti yang baru saja diikuti mencapai $86,67 \%$, aspek keempat yaitu siswa yang merasa paham dengan jelas bahasa yang digunakan dalam perangkat pembelajaran mencapai $86,67 \%$ dan aspek kelima yaitu siswa yang merasa tertarik dengan penampilan (tulisan, ilustrasi/gambar dan letak gambar), yang terdapat dalam perangkat pembelajaran mencapai $88,33 \%$. Maka diperoleh rata-rata persentase aspek respon siswa di atas $80 \%$, maka secara keseluruhan respon siswa berada pada kategori positif.

\section{Analisis Hasil Angket Self Efficacy Siswa pada Uji} Coba I

Data self efficacy siswa dianalisis dengan melihat persentase rata-rataself efficacy siswa pada uji coba I Hasil Rata-rata self efficacy siswa pada uji coba I dapat dilihat pada tabel 2 berikut.

\begin{tabular}{|c|l|l|l|}
\hline No & \multicolumn{1}{|c|}{ Indikatur } & Rata-Rata & $\begin{array}{l}\text { Rata-Rata } \\
\text { Skor Total }\end{array}$ \\
\hline 1 & Tingkat Kesulitan tugas (Level) & 31,57 & \multirow{2}{*}{76,37} \\
\cline { 1 - 3 } 2 & $\begin{array}{l}\text { Derajat kemantapan, keyalinun } \\
\text { atau pengharapan (strength) }\end{array}$ & 19,20 & \\
\hline 3 & Luas bidans perilaku (generculity) & 25,50 & \\
\hline
\end{tabular}

Tabel 2. Rata-rata Skor Self Efficacy

Berdasarkan tabel 2, untuk indikator tingkat kesulitan tugas (level) sebesar 31,57. Derajat kemantapan, keyakinan atau pengharapan (strength) sebesar 19,20 dan Luas bidang perilaku (generality) sebesar 25,60.

\section{Deskripsi Kepraktisan Perangkat Pembelajaran pada Uji Coba 2}

1) Deskripsi Penilaian Validator Terhadap Perangkat Pembelajaran

Analisis berdasarkan respon para ahli dan praktisi menyatakan perangkat pembelajaran berbasis masalah yang dikembangkan secara umum baik dan dapat digunakan dengan sedikit revisi sebagaimana telah dideskripsikan pada uji coba 1 .

\section{2) Deskripsi Keterlaksanaan Perangkat Pembelajaran Uji Coba 2}

\begin{tabular}{|c|c|c|c|c|c|c|}
\hline \multirow[b]{2}{*}{ No } & \multirow{2}{*}{ Aspek yaug Diamati dan Divilai } & \multicolumn{3}{|c|}{ Pertemuan } & \multirow{2}{*}{$\begin{array}{c}\text { Rata- } \\
\text { rata }\end{array}$} & \multirow{2}{*}{$9 \%$} \\
\hline & & I & II & III & & \\
\hline 1 & $\begin{array}{l}\text { Keterlaksanan Rencana Pelabsanaan } \\
\text { Perbelajaran (RPP) }\end{array}$ & 4,11 & 4,56 & 4,44 & 4,37 & 87,4 \\
\hline 2 & $\begin{array}{l}\text { Reterlaksanaan Lembar Alktivitas } \\
\text { Siswa (LAS) }\end{array}$ & 4,25 & 4,25 & 4,50 & 4,33 & 86,67 \\
\hline 3 & $\begin{array}{l}\begin{array}{l}\text { Keterlakssanaan Bulu Pettumiuk Guru } \\
\text { (BPG) dan Buku Siswa (BS) }\end{array} \\
\end{array}$ & 4,20 & 4,00 & 4,00 & 4,07 & 81,33 \\
\hline & Rata-rata Keterlalsanaau & 4,19 & 4,27 & 4,31 & 4,26 & 85,14 \\
\hline & Pers & 83 & 85,37 & 86,30 & & \\
\hline
\end{tabular}

Tabel 3. Keterlaksanaan Pembelajaran Menggunakan Perangkat

Keterlaksanaan pembelajaran menggunakan perangkat pembelajaran yang dikembangkan pada pertemuan pertama, mencapai $83,74 \%$. Pada pertemuan kedua mencapai keterlaksanaan $85,37 \%$. Sedangkan pada pertemuan ketiga mencapai keterlaksanaan $86,3 \%$. Dari hasil deskripsi di atas terkait dengan kepraktisan pembelajaran, kedua indikator dalam penelitian ini mencapai kriteria minimal yang ditentukan sebagai berikut: (1) respon validator terhadap perangkat pembelajaran yang dikembangkan secara keseluruhan baik dan dapat digunakan dengan sedikit revisi, (2) keterlaksanaan pembelajaran menggunakan perangkat pembelajaran yang dikembangkan berada pada kategori baik. Berdasarkan analisis kedua indikator tersebut pada uji coba 2, maka perangkat pembelajaran yang dikembangkan dapat dikatakan praktis.

Deskripsi Keefektifan Perangkat Pembelajaran pada Uji Coba 2

1) Analisis Aktivitas Siswa Uji Coba 2

Data yang dikumpulkan adalah hasil pengamatan aktivitas siswa untuk 3 kali pertemuan. Rata-Rata persentase waktu aktivitas siswa pada uji coba 2 akan dijabarkan pada tabel 4 berikut.

\begin{tabular}{|c|c|c|c|c|c|}
\hline \multirow{2}{*}{ Pertemuan } & \multicolumn{5}{|c|}{ Frekuesi Untuk Setiap Jenis Aktivitas } \\
\hline & 1 & 2 & 3 & 4 & 5 \\
\hline $\mathrm{I}\left(2 \times 40^{\prime}\right)$ & 18,89 & 16,57 & 32,22 & 28,89 & 4,44 \\
\hline II $(2 \times 40)$ & 21,11 & $1 \%, 18$ & 31,11 & 21,18 & 4,44 \\
\hline III $\left(2 \times 40^{\prime}\right)$ & 22,22 & 15,56 & 30,00 & 30,00 & 4,44 \\
\hline Rata-rata & 20.74 & 16.57 & 31.11 & 78.89 & 4.44 \\
\hline Kriteria & $\begin{array}{c}20 \% \leq \\
p W 1 \leq 30 \\
\%\end{array}$ & $\begin{array}{c}10 \% \leq \\
\text { pW } \leq \leq 20 \\
\%\end{array}$ & $\begin{array}{c}25 \% \leq \\
p W / \leq \leq 2 \\
\%\end{array}$ & $\begin{array}{c}25 \% \leq \\
\mu W L \leq 35 \\
\%\end{array}$ & $\begin{array}{c}0 \% \leq \\
\text { pWI } \leq 3 \\
\%\end{array}$ \\
\hline
\end{tabular}

Tabel 4. Persentase rata-rata waktu aktivitas siswa untuk 3 kali pertemuan adalah $20,74 \% ; 16,67 \%$; $31,11 \%$; $28,89 \%$ dan $4,44 \%$.

Secara keseluruhan, terdapat 4 kategori (kategori 1, 3, 4 dan 5) yang telah mencapai persentase waktu ideal yang ditetapkan dan terdapat 1 kategori belum memenuhi persentase waktu ideal, yaitu kategori aktivitas membaca buku siswa dan LKS (kategori 2). Itu berari 3 dari 5 kategori (kategori 4 dan 5 terpenuhi) telah mencapai persentase waktu ideal yang ditetapkan. Dengan demikian dapat disimpulkan bahwa perangkat pembelajaran efektif ditinjau dari aktivitas siswa pada uji coba 2 yang sesuai dengan persentase waktu ideal pembelajaran.

\section{2) Ketuntasan hasil belajar secara klasikal pada uji coba 2}

Hasil ketuntasan pretest kemampuan visual thinking matematis siswa pada uji coba 2 secara klasikal dapat dilihat pada tabel 5 berikut.

\begin{tabular}{|c|c|c|}
\hline Keterangan & Jumlah Siswa & Prosentase (\%) \\
\hline Tuntas & 26 & $86,7 \%$ \\
\hline Tidak tuntas & 4 & $13,3 \%$ \\
\hline
\end{tabular}

Berdasarkan data pada Tabel 5 dan menunjukkan bahwa ketuntasan pos-test kemampuan visual thinking matematis siswa pada uji coba 2 secara klasikal yaitu siswa yang tuntas sebanyak 26 siswa $(86,7 \%)$, sedangkan siswa yang tidak tuntas sebanyak 4 siswa ( $13,3 \%)$ dari 30 siswa yang mengikuti pos-test kemampuan visual thinking matematis. Pada uji coba 2 ketuntasan secara klaskal sebesar 86,7 \% ini berarti sudah mencapai kriteria ketuntasan secara klasikal yang di tetapkan sebesar $80 \%$.

\section{3) Analisis Respon Siswa Uji Coba 2}

Data yang dikumpulkan adalah hasil pengamatan aktivitas siswa untuk 3 kali pertemuan. Rata-Rata

Pengembangan Perangkat Pembelajaran Berbasis masalah untuk Meningkatkan Kemampuan Visual Thinking dan Self-Efficacy Siswa Kelas VII SMP Swasta raja Garuda MAS Besitang 
Vol. 13, No. 2, Desember 2020

persentase waktu aktivitas siswa pada uji coba 2 akan dijabarkan pada table 1.13 berikut.

\begin{tabular}{|c|c|c|c|}
\hline \multirow[b]{2}{*}{ No } & \multirow[b]{2}{*}{ Aspek } & \multicolumn{2}{|c|}{$\%$ Rata-Rata } \\
\hline & & Senang & $\begin{array}{l}\text { Tidak } \\
\text { Senang }\end{array}$ \\
\hline 1 & $\begin{array}{l}\text { Perasaan senang siswa } \\
\text { perangkat pembelajaran. }\end{array}$ & 88.67 & 11.33 \\
\hline & & Baru & Tidak Baru \\
\hline 2 & $\begin{array}{l}\text { Rcspcn siswa tcrhadap kcbaruan } \\
\text { peranglat pembelajaran. }\end{array}$ & 90,00 & 10,00 \\
\hline & & Berminat & $\begin{array}{c}\text { Tidak } \\
\text { Berminat }\end{array}$ \\
\hline 3 & $\begin{array}{l}\text { Respcn siswa terhadap keberminatan } \\
\text { mengikuti pembelajaran selanjutnya. }\end{array}$ & 90.00 & 10.00 \\
\hline & & $\mathbf{Y a}_{\mathbf{a}}$ & Tidak \\
\hline 4 & $\begin{array}{l}\text { Respon siswa teriaciap kajelasan bahasa } \\
\text { yang digunakan pada perangl:at } \\
\text { pembelajaran. }\end{array}$ & 91.67 & 8.33 \\
\hline & & Ya & Tidak \\
\hline 5 & $\begin{array}{l}\text { Respon siswa terhadap ketertarikan } \\
\text { pada pcnampilan pcrangkat } \\
\text { pembelajaran. }\end{array}$ & 91,67 & 8,33 \\
\hline & Rata - rata keseluruhan & 90,00 & 10,00 \\
\hline
\end{tabular}

Dapat dilihat bahwa hasil persentase dari aspek pertama yaitu siswa yang merasa senang terhadap komponen pembelajaran mencapai 88,67\%, aspek kedua yaitu siswa yang merasa bahwa komponen perangkat pembelajaran tergolong baru mencapai $90,00 \%$, aspek ketiga yaitu siswa yang merasa berminat dalam mengikuti kegiatan pembelajaran selanjutnya seperti yang baru saja diikuti mencapai 91,67\%, aspek keempat yaitu siswa yang merasa paham dengan jelas bahasa yang digunakan dalam perangkat pembelajaran mencapai $91,67 \%$ dan aspek kelima yaitu siswa yang merasa tertarik dengan penampilan (tulisan, ilustrasi/gambar dan letak gambar), yang terdapat dalam perangkat pembelajaran mencapai 91,67\%. Maka diperoleh rata-rata persentase aspek respon siswa di atas $90 \%$., maka secara keseluruhan respon siswa berada pada kategori positif.

Analisis Angket Self Efficacy Siswa Terhadap Matematika Pada Uji Coba 2

\begin{tabular}{|c|l|ll|l|}
\hline No & \multicolumn{1}{|c|}{$\begin{array}{c}\text { Indikator Disposisi } \\
\text { Matematis }\end{array}$} & Rata-Rata & $\begin{array}{l}\text { Rata-Rata } \\
\text { SkorTotal }\end{array}$ & Presentase \\
\hline 1 & Tingkat Kesulitan tugas (Level) & 31,60 & \\
\hline 2 & $\begin{array}{l}\text { Derajat kemantapan, keyakinan } \\
\text { atau pengharapan (strength) }\end{array}$ & 19,90 & $80,8 \%$ \\
\hline 3 & $\begin{array}{l}\text { Luas bidang perilaku } \\
\text { (generality) }\end{array}$ & 25,07 & \\
\hline
\end{tabular}

Tabel 6. Rata-Rata Self Efficacy Siswa Pada Uji Coba 2

Tabel diatas menunjukkan bahwa rata-rata indikator menunjukkan peningkatan pada ujicoba 2, indikator Tingkat Kesulitan Tugas (level) menjadi 31,60, derajat kemantapan, keyakinan atau pengharapan (strength) meningkat menjadi 19,90 dan yang terakhir Luas bidang perilaku (generality) menjadi 26,07 Indikator tertinggi yaitu indikator Tingkat Kesulitan Tugas (level), Luas bidang perilaku (generality), terakhir yaitu indikator kemudian diikuti keyakinan atau pengharapan (strength). Dengan demikian dapat disimpulkan bahwa self efficacy matematis siswa pada uji coba 2 dominan melihat dari segi tingkat kesulitan tugas.

Setelah diperolehnya perangkat pembelajaran yang valid, praktis dan efektif telah terpenuhi pada uji coba 2 , maka perangkat pembelajaran dapat digunakan untuk melihat peningkatan kemampuan visual thinking dan self efficacy siswa.

\section{KESIMPULAN}

Berdasarkan hasil analisis dan pembahasan dalam penelitian ini, dikemukakan beberapa kesimpulan sebagai berikut:

1. Perangkat pembelajaran berbasis masalah yang dikembangkan memenuhi kriteria valid. Perolehan nilai rata-rata total validitas RPP sebesar 4,56; Buku Guru sebesar 4,43; Buku Siswa 4,37; LAS sebesar 4,56 serta butir tes kemampuan visual thinking matematis siswa butir pernyataan dan angket self efficacy juga telah berada pada kategori valid.

2. Perangkat pembelajaran berbasis masalah yang dikembangkan memenuhi kriteria praktis. Kriteria kepraktisan ditinjau dari: (1) penilaian validator terhadap perangkat pembelajaran secara keseluruhan baik dan dapat digunakan dengan sedikit revisi; (2) keterlaksanaan perangkat pembelajaran pada uji coba 2 mencapai $85,14 \%$ dengan kategori baik.

3. Perangkat pembelajaran berbasis masalah yang dikembangkan memenuhi kriteria efektif. Kriteria efektif ditinjau dari: (1) ketuntasan hasil belajar siswa secara klasikal dengan nilai minimal 2,67 telah mencapai $86,67 \%$ pada uji coba 2 ; (2) aktifitas siswa pada seluruh aspek yang diamati berada pada batas toleransi waktu ideal yang ditetapkan; dan (3) banyak siswa yang memberikan respon positif terhadap kegiatan dan perangkat pembelajaran yang dikembangkan mencapai 90,00\%.

4. Peningkatan kemampuan visual thinking siswa menggunakan perangkat pembelajaran berbasis masalah yang dikembangkan pada materi persamaan dan pertidaksamaan linear satu variabel ditinjau dari presentase pencapaian sebesar 9,97\%. Ketuntasan kemampuan siswa pada uji coba 1 sebesar 76,7 meningkat menjadi 86,67 pada uji coba 2 .

5. Peningkatan self efficacy siswa diperoleh dari total rata-rata self efficacy pada uji coba 1 sebesar 76,37 dan uji coba 2 sebesar 77,57. Peningkatan pada indikator level sebesar 0,3, indikator strenght sebesar 0,7 indikator generality sebesar 0,47. Presentase pada uji coba 1 sebesar 79,5 sedangkan pada uji coba 2 sebesar 80,8 \%. Dari data uji coba dan 2 dapat disimpulkan bahwa pada uji coba membawa perubahan positif terhadap perangkat pembelajaran yang di kembangkan. Dilihat dari total rata-rata pada uji coba 2 menunjukan kemampuan self efficacy siswa menunjukan kategori baik/ sangat baik. Selain itu pada presentase juga menunjukan respon positif yaitu $80,8 \%$.

\section{REFERENSI}

Abdurrahman, M. 2009. Pendidikan bagi Anak Berkesulitan Belajar. Jakarta: Rineka Cipta

Ariawan, R. 2016. Pengaruh Pendekatan Pembelajaran Visual Thinking Disertai Aktivitas Quick On The Draw Terhadap Kemampuan Komunikasi Matematis Siswa. Suska Journal of Mathematics Education. Vol.2, No. 1, 2016, Hal. 20 - 30. 
Arends, Richard I. 2008. Learning to teach. Penerjemah: Drs. HellyPrajitno, M.A dan Dra.Sri Mulyantini Soetjipto.Yogyakarta: Pustaka Pelajar.

Bandura. 1997. Self Efficacy: The Exercise of control. New York: W. H. Freeman and Company.

Bandura . 2006. Self Efficacy Cambridge: Cambridge University Press.

Boud, Felletti. (2000), The Challenge of Problem Based Learning, London :Kogan Page.

Depdiknas. 2006. Permendiknas No. 22 Tahun 2006 Tentang Standart Isi. Jakarta: Depdiknas.

Hasraratuddin.2013 Membangun karakter melalui pembelajaran matematika, Paradikma Vol. 6 Nomor 2. ISSN 1978-8002.

Hosnan. 2014. Pendekatan Saintifik dan Kontekstual dalam Pembelajaran Abad 21. Jakarta:Galian Indonesia

Hutagaol, Kartini. 2013. Pembelajaran Kontekstual Untuk Meningkatkan Kemampuan Representasi Matematis Siswa Sekolah Menengah Pertama. Infinity Jurnal Ilmiah Program Studi Matematika STKIP Siliwangi Bandung, Vol 2, No.1, Februari 2013.

Novrini. (2015). Pengembangan Perangkat Pembelajaran Berorientasi Problem Based Learning untuk Meningkatkan Kemampaun Visual Thinking dalam Pemecahan Masalah Matematis Siswa Kelas VIII SMP.Tesis. Tidak diterbitkan.

Ramadanti, R. (2016). Peringkat Pendidikan Indonesia masih Rendah..

Samosir, K. dan Siahaan,S., 2014. Penerapan Model Pembelajaran Kooperatif Tipe STAD yang Berorientasi Pada Pembelajaran Berdasarkan Masalah Pada Matematika Diskrit 2. Jurnal PARADIKMA, Vol.7(1) Halaman 12-23

Sapta,A.Hamid, A. Syahputra, E. 2018. Assistance of Parents In Learning At Home: IOP Conf. Journal of Physsics. Series 1114.

Surya, E. 2013. Peningkatan Kemampuan Representasi Visual Thinking pada pemecahan Masalah matematis dan Kemandirian Belajar siswa SMp Melalui Pembelajaran Kontekstual Universitas Pendidikan Indonesia. Disetasi. Bandung. PPs Universitas Pendisikan Indonesia.

Surya, E. \&_Syahputra, E. 2017. Improving High-Level Thinking Skills By Development Of Learning PBL Approach On The Learning Mathematics For Senior High School Students. Published by Canadian Center of Science and Education.International Education Studies; Vol. 10, No. 8; 2017.ISSN 1913-9020 EISSN 1913-9039

Thiagarajan, S. Semmel, D.S. Semmel, M. (1974). Instructional Development for Training Teachers of Exceptional Children. A Sourse Book. Blomington: Central for Innovation on Teaching The Handicapped.

Trianto. 2007. Mendesain Model Pembelajaran Inovatif Progresif. Konsep Landasan, dan Implementasinya pada KTSP. Jakarta: Kencana Prenada Media Group.

Wiyana. 2013. Pengaruh Pengetahuan KTSP dan Pendidikan Terhadap Kemampuan Menyusun RPP Guru SDN Jatiyoso Tahun 2011/2012. Jurnal Teknologi Pendidikan, 1 (2): 239-248. 